\title{
Social Status Changes of Women Garments Worker: A Study on Bangladesh Perspective
}

\author{
Dr. Kamrun Nahar ${ }^{1^{*}} \quad$ Mohammad Shahjahan $^{2}$ \\ 1.Assistant Professor, Department of Social Work, Sheikh Borhanuddin Post Graduate College, 62, Nazimuddin \\ Road, Dhaka, Bangladesh \\ 2.Institute of Social Welfare and Research, University of Dhaka, Bangladesh
}

\begin{abstract}
Garments industry is the prime economic sector in Bangladesh. Most of the GDP (Gross Domestic Product) carried on Garments Industry. In this industry most of the worker is women. So, women garment worker are main human resources in Bangladesh. But one problem is that, they have no standard social status in our society on the other hand they have owned social status after joining the garments industry. Basically, before joining the garments industry women have lower social status or have no status in her family, relatives, and her father in laws house. Women deprived from control over resources, have no decision-making power, no invitation in social functions, poor health service etc. But this scenario changes after joining the garments industry. In that perspective researcher applied quantitative research methods to find out how to change social status of women garments worker. In the quantitative method researcher followed simple random sample survey into the garments industry where women are working. Researcher found some recommendations from the women garment's worker. At first, they have an occupational identity which is helpful to consume social status in her family as well as in her relatives. So, it is a great change for women with help of garments industry. The change social status process is not easy because various problems hamper this changes system. Sometimes women garment worker harassed by her family members as well as her colleagues, staffs of garments, owner of the garments etc. In this situation a woman is helpless in her life and they need to support from her family members, friends, colleagues, staffs and owner. In this context, researcher finds out the women to manage this situation it is a great change in social status of women garments worker in Bangladesh. Women garments worker think that if they have regular work in garments factory as well as they get social, economic, and legal support from stakeholder (Garments Industry, Government, Media etc.) their social status changes well radically.
\end{abstract}

Keywords: Social Status, Change, Women Garment Workers, Bangladesh

DOI: $10.7176 /$ RHSS/11-14-03

Publication date:July $31^{\text {st }} 2021$

\section{Introduction}

The garment sectors are essential in our national life for economic growth. People want to decorate themselves with cloths at reasonable prices which will uphold their dignity. As a result, the garments sectors are established for serving our demand as well as boosting our country for the recognition of being a developing country. Bangladesh is a proper place to achieve goal through promoting ready-made garment factories because of its low labor cost and abundance of raw materials. So, the garment factories are built here and there in the country. The developed countries are interested to do their business with us. Now the numbers of garment factories are 4328 and the numbers of workers employed in these factories are 4 million in 2015-2016 year (BGMEA). The readymade garments industry acts as a catalyst for the development of Bangladesh. The "Made in Bangladesh" tag has also brought glory for the country, making it a prestigious brand across the globe. Bangladesh, which was once, termed by cynics a "bottomless basket", has now become a "basket full of wonders." The country with its limited resources has been maintaining 6\% annual average GDP growth rate and has brought about remarkable social and human development.

There are many international political and economic organizations helping the garments industries because of low labors cost and the easy availability of the raw materials (Majumder and Jahir 1994:1). The recruitment of workers in garments depends on their physical ability, tolerance, stillness and experience. The dignity of work, responsibility and the cordiality etc. are related to their getting salary. Moreover, the garments workers have to deal with numerous problems in their family life. It is published in the International Labour Organization (ILO) about the fundamental rights and inhuman condition. It depends on their getting the right in the ever way. However, now the apparel industry in Bangladesh is the biggest export earner industry with the value of over \$25.49bn of exports in 2014-15 financial years.

On the other hand, the garment sectors remarkably developed due to the globalization. (Majumder 2003:295). But the women are deprived from initial period. They did not get their legal benefits from there sections. (Majumder and Jahir 1994) Most of the women are deprived because of there are thousands of labours working in the same situation in the garment sector of Bangladesh, making it difficult for them to ask for more facilities and salaries then the present condition. Above all, the gender discrimination is still very high in our 
country and women workers are defrauded.

It is very difficult to bear the family expenses by their salary. For instance, they suffer from many diseases and can't afford to get proper medication. Many of their husbands are drug addicted and ill tempered. They take all of the salary and torture the women physically. Besides, they maintain their family by doing the household works by themselves although they have to attend their work at day regularly. Above all, they don't get their proper facilities from the society after working all day. Moreover, they are always neglected by the society. This is the circumstances of the garment's workers in our country. The problems are increasing day by day economically and socially because of long-time duty, ill-treated by authorities, less salary, irregular salary, lack of social safety. Want of fundamental elements, such as: food, cloths, living place and proper facilities.

The women workers are facing various hazardous conditions in the working place. Thus, they cannot contribute themselves for the socio-economic problems. It is the duty of the authorities to ensure their salaries with health facilities by ILO convention. There is no trade union of labors. The labor especially the women workers are deceived from their job. As a result, the environment at work place is inversing day by day.

So, at the time of panic caused from accidents workers try to rush out from the garments all at the same time and many of them die from trampling. For example, there are 54 labors injured by firing and finally died at the courts of a garment in Kalurghat on the 23rd February 2006. Eventually, most of the Garments authority is neither follows the rules nor maintains the legal rights of workers. There is no child care facility in garments factories in Bangladesh and it is an inhuman heartless system for children and its mother. In spite of feeling this problem they are bound to be silent about their job (Reza, 2005: 28)

\section{Objectives of the Study}

The main objective of this study is to know the social status changes of women garment workers in Bangladesh. However, the specific objectives of the study are follows:

- To know the social status of women garment workers;

- To assess the social status of women garment worker after joining the garments industry;

- To identify the changes of social status of women garments worker in Bangladesh; and

- To determine the opportunities to improve the social status of women garments worker.

\section{Conceptual Framework}

Conceptual framework of the study is the main research talking point which is enriching the research paper. As such, establishing this framework provides an opportunity to identify interlinkages that could potentially contribute to the overall outcome of the research undertaking. This part describes the study issues where as interlinkages with concept as well as theory. This framework chances to identify the changes of social status through joining the garments industry and contributes to find out the outcome of the research paper. This framework has also established research hypotheses that are important to examine whether the garments industry is helping the women by changing their social status. At first the brief discussion of the essential variables of the study as well as the other related variables which influence the social status changes of women garments worker are presented onwards. 


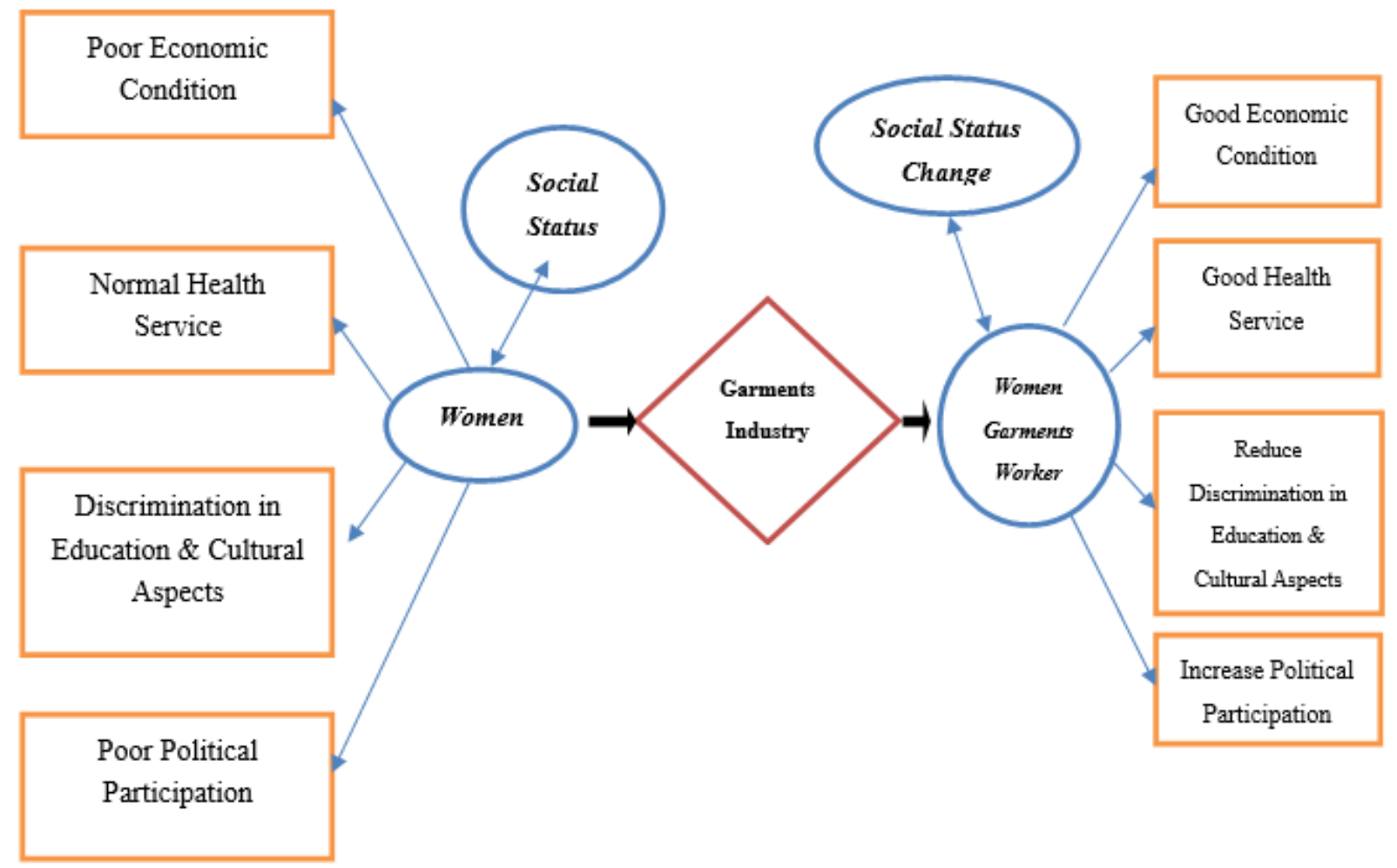

Figure 1. Conceptual Framework

Based on all the above-mentioned concepts and previous theoretical findings, and definitions of important variables, the conceptual framework of the study is developed. This framework analyses the condition of women as well as changes condition after joining the garments industry. In general, a woman lives in poor economic condition into the poor family. They got normal health service from the govt. hospitals because they did not bear the high cost of medical services in the private medical. They also discriminate in education and cultural aspects from the family members. Most of the women got primary education and poor participation in cultural activities. Political participation like decision making, social movement, member of union or organization etc. is poor due to lack of interest where as poor women did not fulfil their basic needs. In all these previous conditions a woman wish to join the garments industry and most of the women are migrated from rural area to urban area.

They are joining different garments industry in industrial areas like Gazipur, Savar, Narayanganj etc. After join the garments changes their status as Women Garments Worker. Women garments worker try to change social status. At first stage they change economic condition, they have to economic solvency. Then women garment worker gets better health facilities in govt. and private hospitals as well as they support their children in education and cultural activities. They have to wish that increase their political participation into the family and society. They also join in various union and organizations to achieve their rights.

\section{Methodology of the Study}

This study assumed quantitative approach because prior studies regarding public administration aims to find out solutions in public problems and feeds the various supportive statements from existing research outcomes. To prove conceptual framework the research applied quantitative methods. Quantitative method of enquiry through survey instrument is described in context with empirical data for examining reliability and validity. One of the most common and well-known study designs in public administration is the cross-sectional study design because in cross sectional study subset of a specific population (sample) is selected at a given time point. In cross sectional study, data is collected from individuals to get answer of research questions to reach to the results.

The study is conducted to that area in Bangladesh where garments are located. So, the sample of individuals is interviewed in different garments in Bangladesh. Purposively Dhaka, Narayangonj, and Gazipur districts were selected in the study area. Five garment industries (Fashion Wear Garments Ltd., Gazipur, Fartex Fashion Wear Ltd., Gazipur, Rony Textile Mills, Narayanganj, Rupshi Garments, Narayanganj, and Prime Garments Ltd., Narayanganj) were selected. The study area was selected based on researcher accessibility. In this study we intend to know whether the social status of the female garments worker in Bangladesh has been changed or not. So, our respondents were the female workers of the selected garments.

The sampling design was simple random sampling (SRS) for this study where each and every item in the population has an equal chance of inclusion in the sample and each one of the possible samples, in case of finite 
universe, has the same probability of being selected.

The formulas discussed basically are the different representation of the same formula and most commonly used in simple random sampling. According to this method, in order to determine the size of the sample by simple random sampling the required formula is,

Where,

$\mathrm{n}=$ sample size

$\mathrm{z}=$ standard normal deviate

$\mathrm{p}=$ assumed proportion in the target population

$\mathrm{d}=$ degree of accuracy desired in the estimated proportion

This is called Cochran's Formula and it is used when we don't have much information about the subjects and the survey topic. It is conventional and usual practice to select the proportion to be 0.5 when we don't have enough information to move on for more complex sampling scheme. (An Introduction to Sampling Methods, M.Nurul Islam, Third Edition, page 85)

Here,

$\mathrm{z}=1.96$

$\mathrm{p}=0.5$ (assumed).

Here the assumption is based on (Shanjida Shahab Uddin, March 25, 2015 South Asian Journal) where it was told that of the approximately 4.2 million workers in the RMG industry around $85 \%$ are women workers. Here our target population is the entire female garments worker in Bangladesh and we can safely assume without harming the study purpose that half of the female garment's workers have experienced social status change.

$\mathrm{q}=1-\mathrm{p}=1-0.5=0.5$

$\mathrm{d}=0.05$

Therefore, $\quad=384.16 \approx 385$.

For our study we have rounded the figure to 400 and collected data on 400 respondents.

A questionnaire is designed to collect information by engaging respondents in a special kind of topic and this topic is discussed through conversation via face-to-face interview. Open ended and close ended questions have been used to collect information from the respondents. To make questionnaire more acceptable a pilot test of the questionnaire was conducted to make sure it is understandable and in pilot testing also involved evaluation of reliability and accuracy of measurements.

After collecting data from the field, each questionnaire was checked carefully and tried to remove the inconsistencies and to eliminate omissions. All the analysis created tables, the chi-square test, and measure of association tests have been done by using SPSS software. The reports are written in Microsoft word 2007.

\section{Findings of Study}

The study conducted to find out the change's social status of women garments worker in Bangladesh. Women are highly deprived group in our society especially they have no contribution in the family. Women have lower social status before joining the garments job. But this scenario is changes after joining the garments industry. In this context researcher find out the social status of women garments worker, to know the previous social status of women before joining the garments and after joining the garments industry, to identify the problems of women garments worker. At last, role of stakeholders in changing social status of women garments worker. 


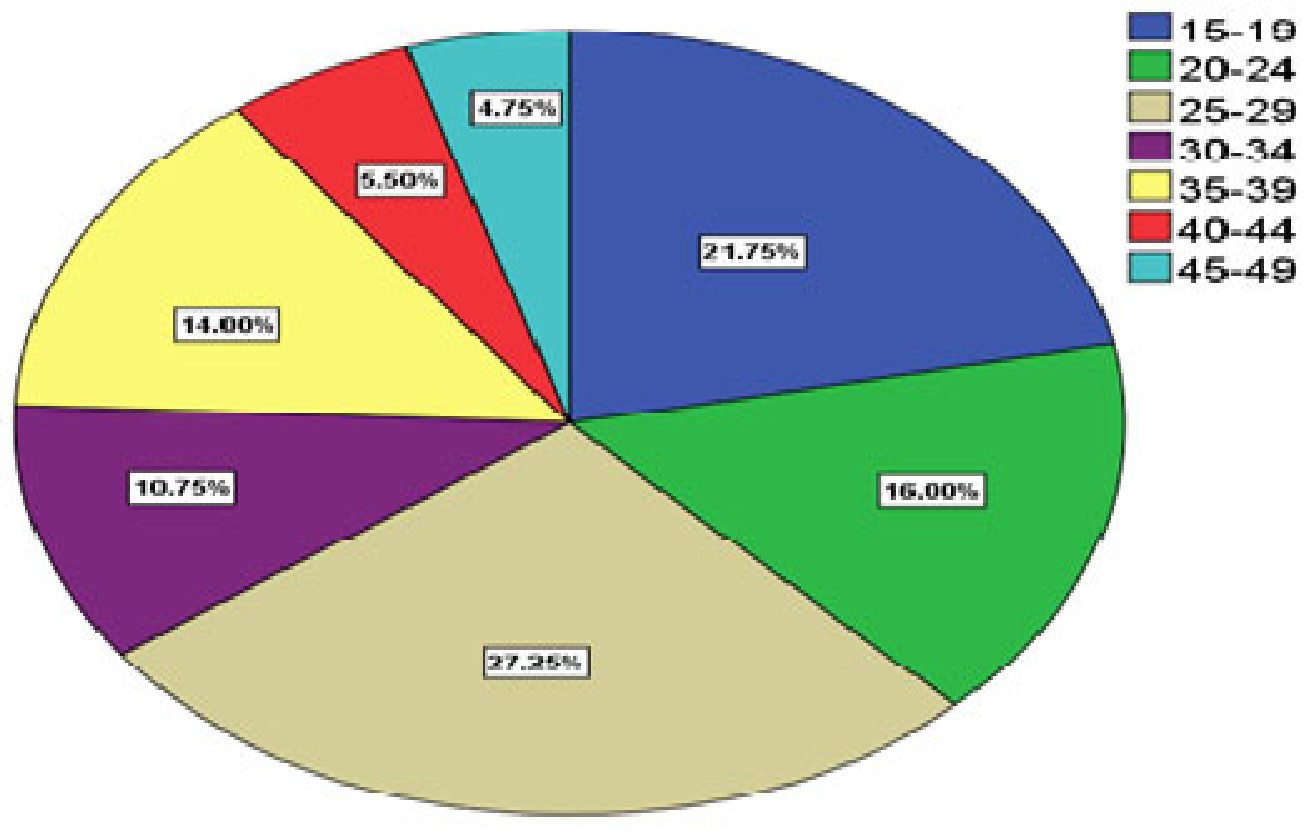

Figure 2. Age of respondents

This pie diagram shows that $27.25 \%$ respondent's age is $25-29$ years old on the other hand only $4.75 \%$ respondent is aged between 45-49 years old. So, age is important for garments work because garments owner want to young age people so that they work more time as well as they are capable to give more production.

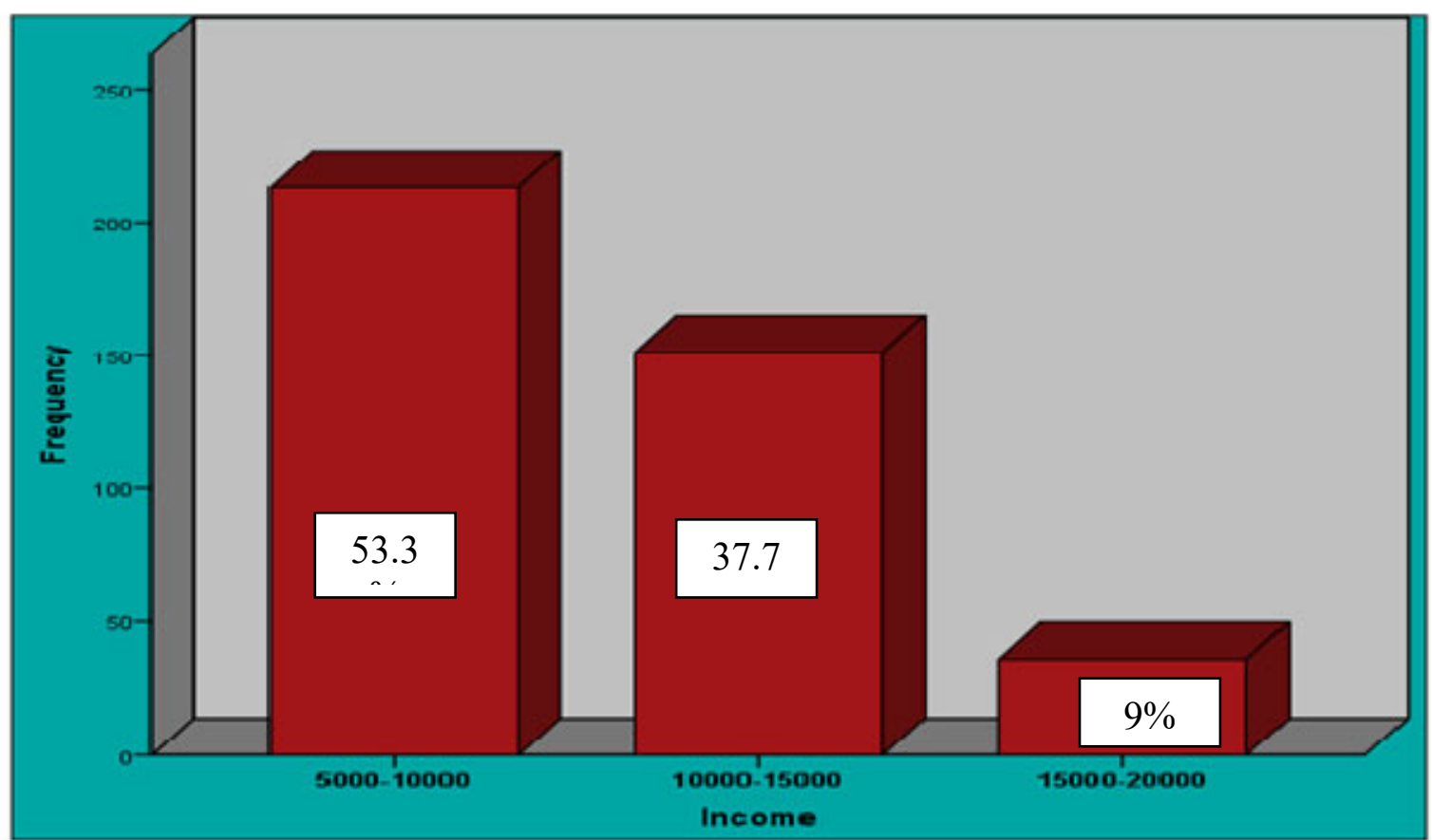

Figure 3. Income of the respondents

The bar diagram shows that 53.3\% respondents are salaried between 5000-10000 taka as well as only $9 \%$ of the respondents get between 15000-20000 tk. So, in that context we can say that most of the women garment workers do not get sufficient salary to develop their social status. 


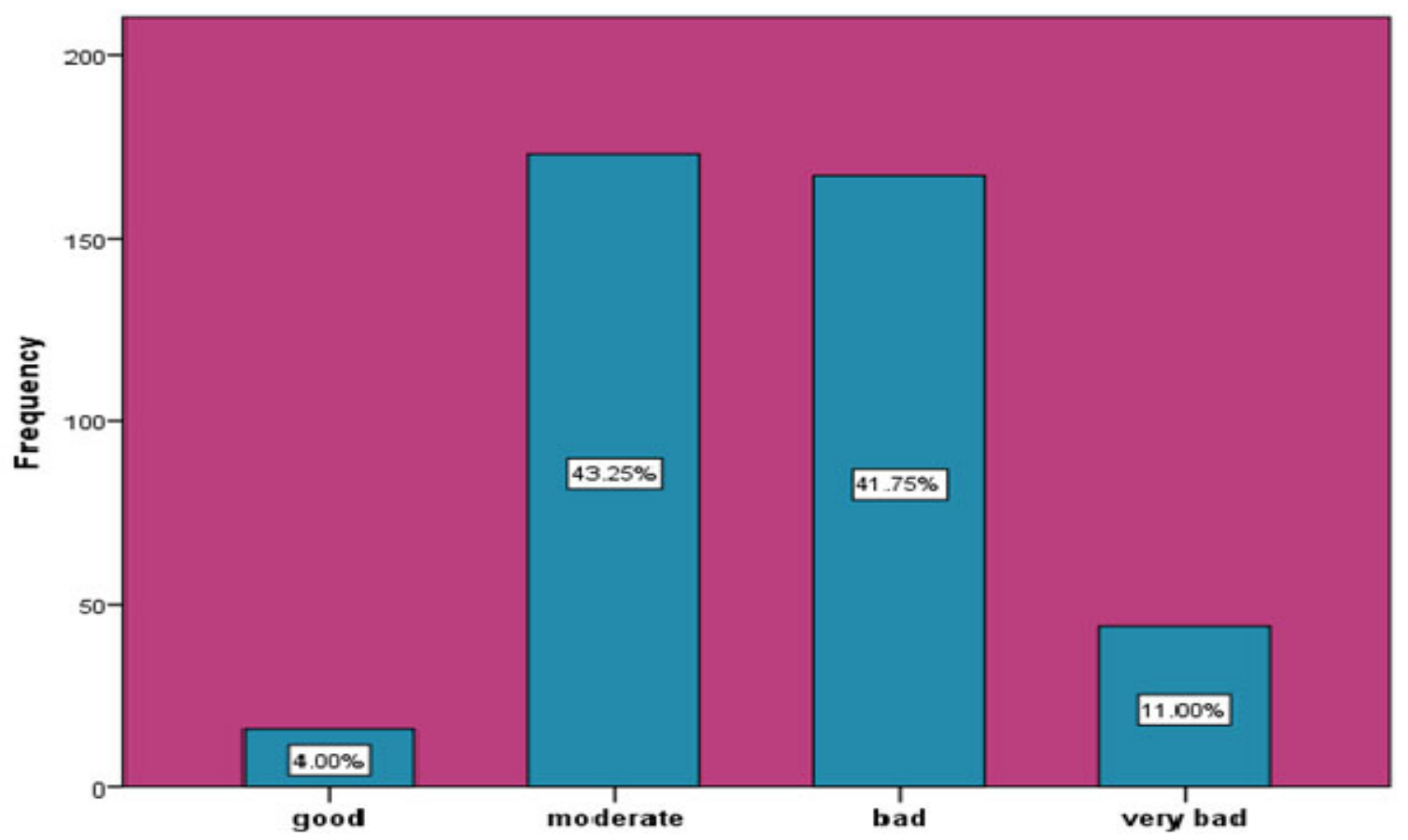

Figure 4. Pre social status in family

In our country most of the garment's workers belong to lower class of the society due to poverty. So, in that situation social status of a woman garments worker is not good before joining the garments industry. In this context researcher found that among women garments workers $43.3 \%$ respondents said they had moderate social status in their family as well as $41.8 \%$ respondents said to have bad social status in their family. Also $11 \%$ responded that they had very bad social status before joining garments industry.

On the other hand, only $4 \%$ respondents said that they had good social status in their family. So, we can say that in our country perspective most of the women garment's worker had moderate and bad social status in their family.

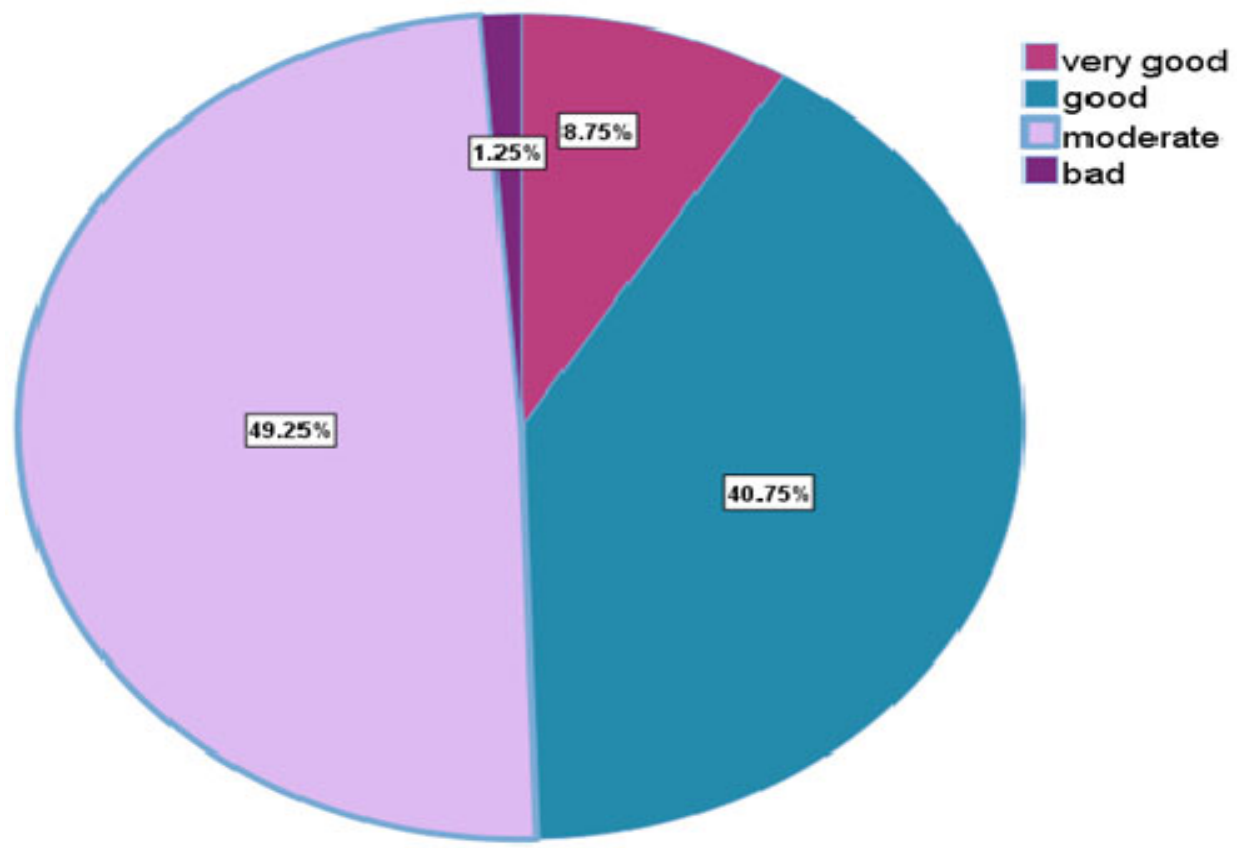

Figure 5. Post social status in family

This situation arises when women try to change their social status in their society and family. So, for doing this they are coming in the city area and joining the garments industry because it is easier to have compared to another job. In this context researcher found that among the respondents $49.3 \%$ respondents said to have 
moderate social status in their family level as well as $40.8 \%$ respondents said to achieve good social status in their family level.

So, we can say that it is a radical variation before joining the garments industry. So, women joining the garments industry may change their social status in family level.

Table 1. Pre social status in relatives

\begin{tabular}{|c|c|c|c|}
\hline Variable name & Categories & Frequency & Percent \\
\hline \multirow{3}{*}{$\begin{array}{c}\text { Pre social status } \\
\text { in relatives }\end{array}$} & Bad & 33 & 8.3 \\
\cline { 2 - 4 } & Good & 178 & 44.5 \\
\cline { 2 - 4 } & Medium & 180 & 45.0 \\
\cline { 2 - 4 } & very bad & 9 & 2.3 \\
\cline { 2 - 4 } & Total & 400 & 100.0 \\
\hline
\end{tabular}

Researcher tries to find out the status of a women garments worker in relatives before joining the garments. Frequency table shows that $45 \%$ said to have moderate situation and $44.5 \%$ good as well as $2.3 \%$ women garments worker said to have very bad social status in relatives before joining the garments.

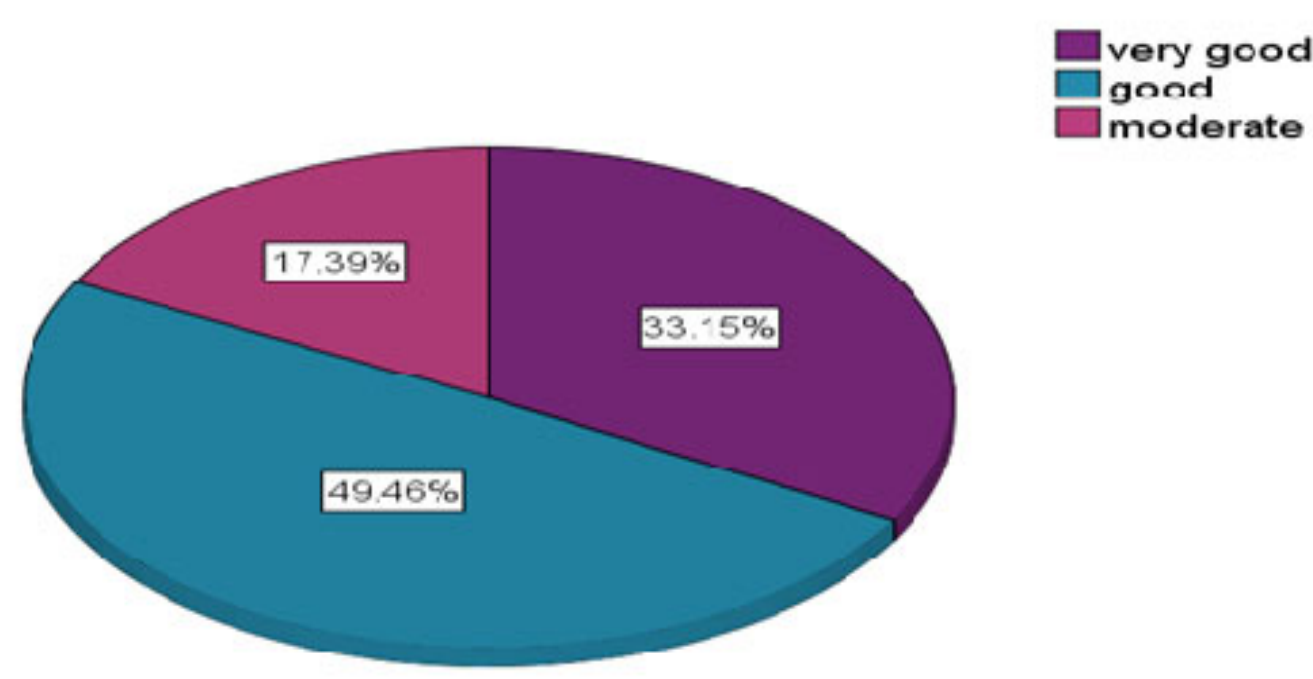

Figure 6. Post social status in relative

After joining the garments industry women garment worker's social status in relatives may change. Pie diagram shows that $49.6 \%$ said they have good status and $33.15 \%$ respondents said they have very good social status in relatives after joining the garments industry.

So, we see that when women join in garments industry their social status changes in relatives which may influence to increase their social status. 


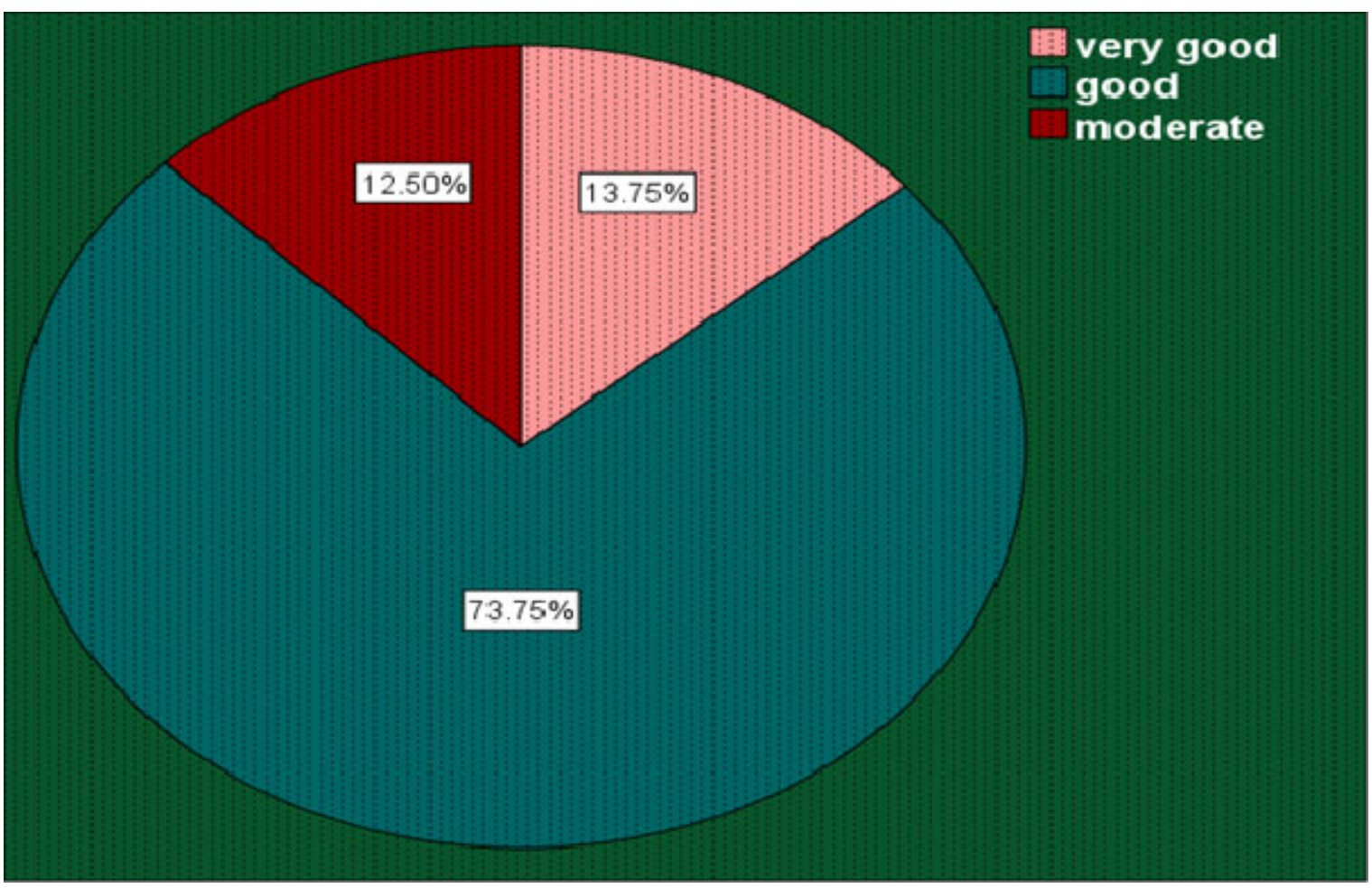

Figure 7. Post invitations in social functions

After joining the garments industry invitation in social function is increased rather than before joining the garments industry. Table shows that $73.75 \%$ respondents said that good, $13.75 \%$ respondents said very good and $12.5 \%$ women garments worker said moderate stage of invitation in social functions by her relatives. So, garments job gives priority of a women in the context of invitation in social functions which was not possible before joining the garments industry.

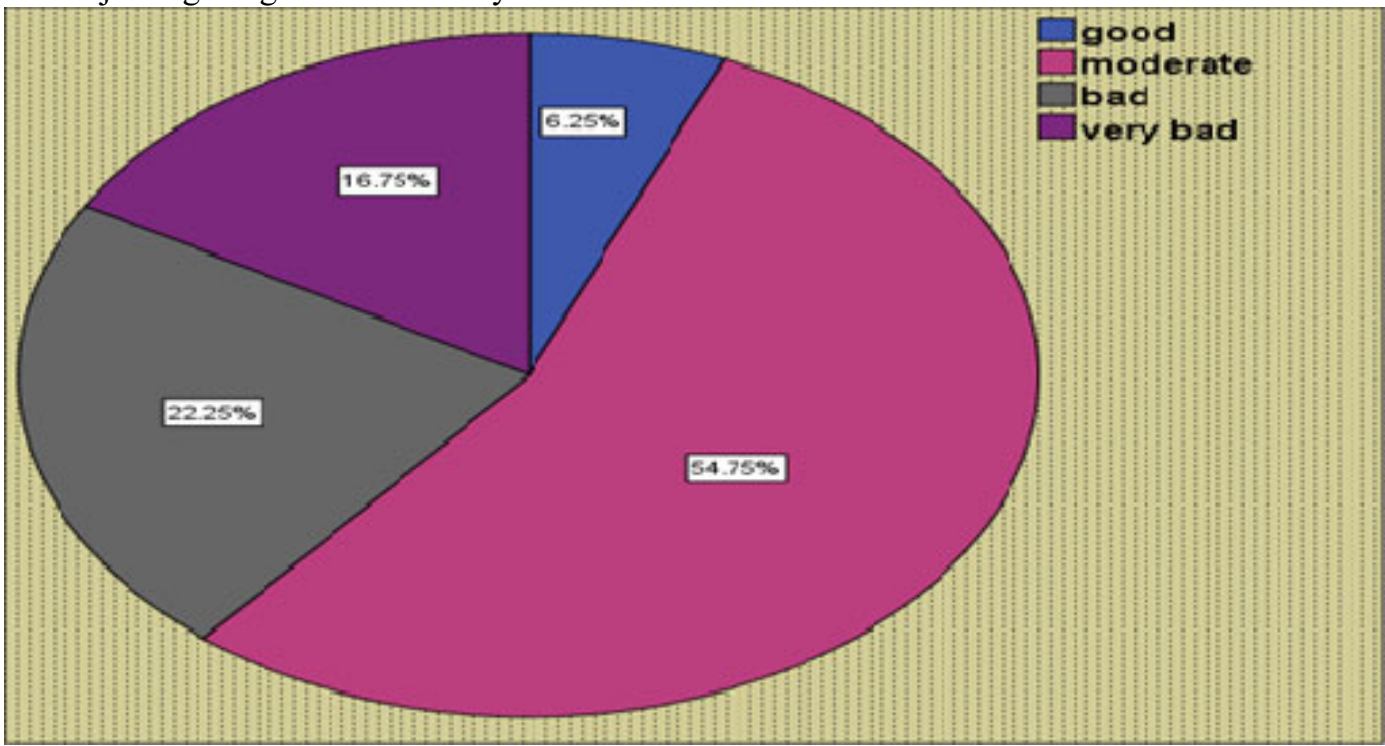

Figure 8. Pre decision making power in family

Decision making in society \& family is less important for women because most of the decision making is done by her parents or big brother or husband. Researcher finds out the scenario of decision-making power in society before joining the garments industry. Diagram shows that $54.8 \%$ respondents said moderate, $22.3 \%$ women garments worker said bad and $16.8 \%$ said very bad as well as only $6.3 \%$ respondents said good. 


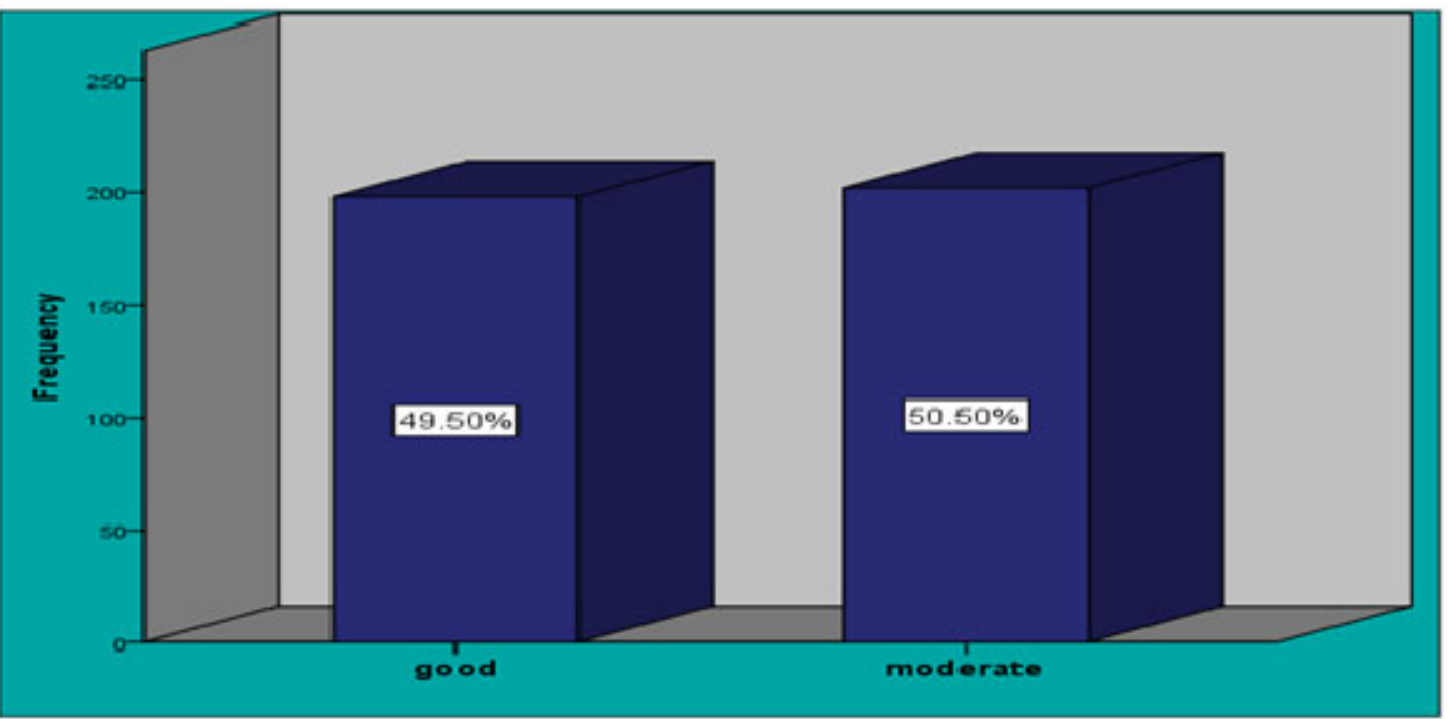

Figure 9. Post decision making power in family

After joining the garments industry decision making power of a woman is changed. Bar chart shows that $50.5 \%$ said moderate and $49.5 \%$ said good condition in her family. Now they can take decision in any important issues. It is only possible due to her job as well as her economic contribution in her family so most of women join garments industry.

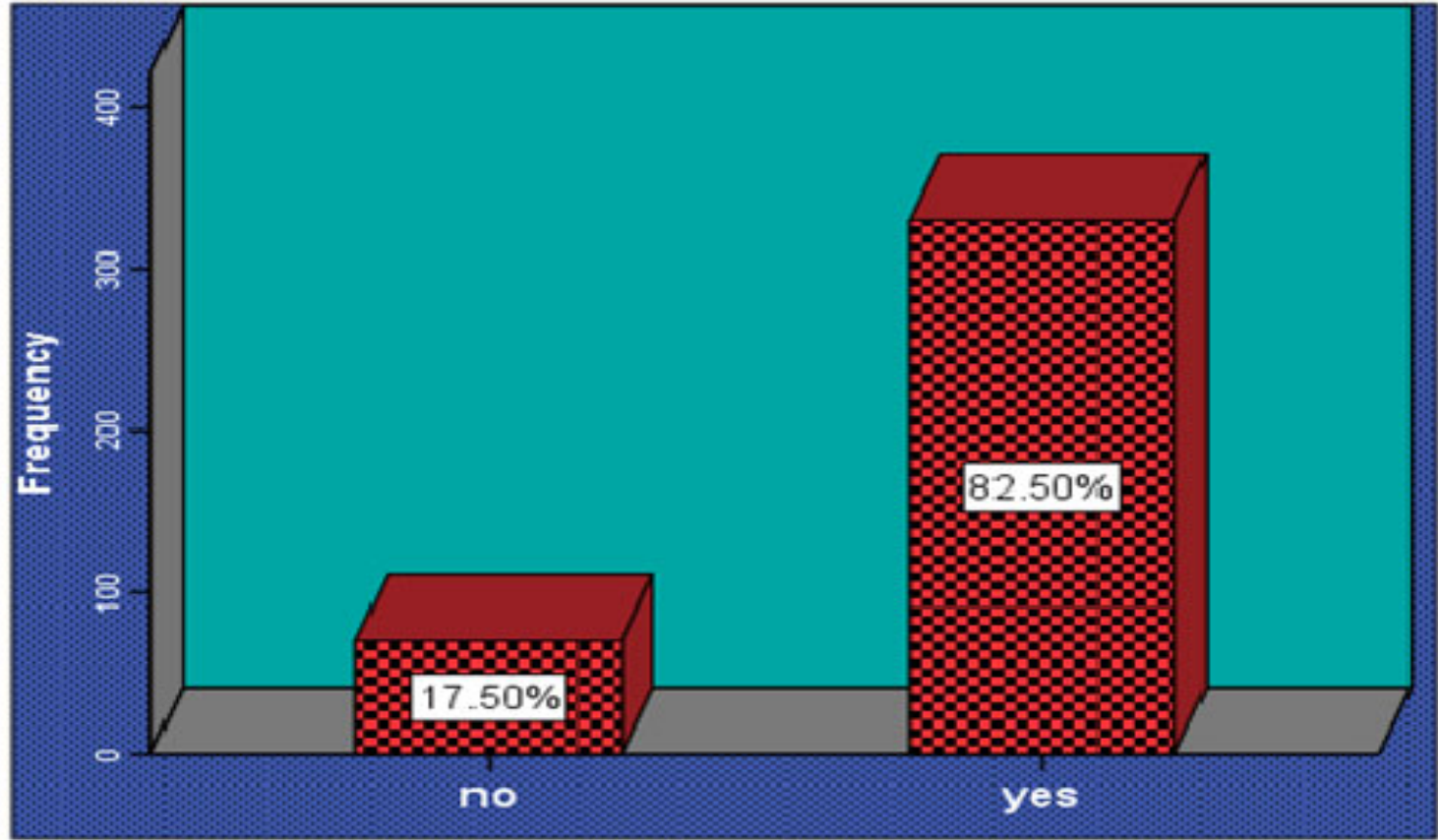

Figure 10. Garment's job increases your social status

Researcher thinks that garments job has people's recognition in our country. Especially women are more popular as garments worker in Bangladesh. Figure shows that $82.5 \%$ respondents said yes and $17.5 \%$ women garments worker said no to the question regarding whether joining garments has improved their social status or not. So, this scenario is positive that garments job increases social status. 


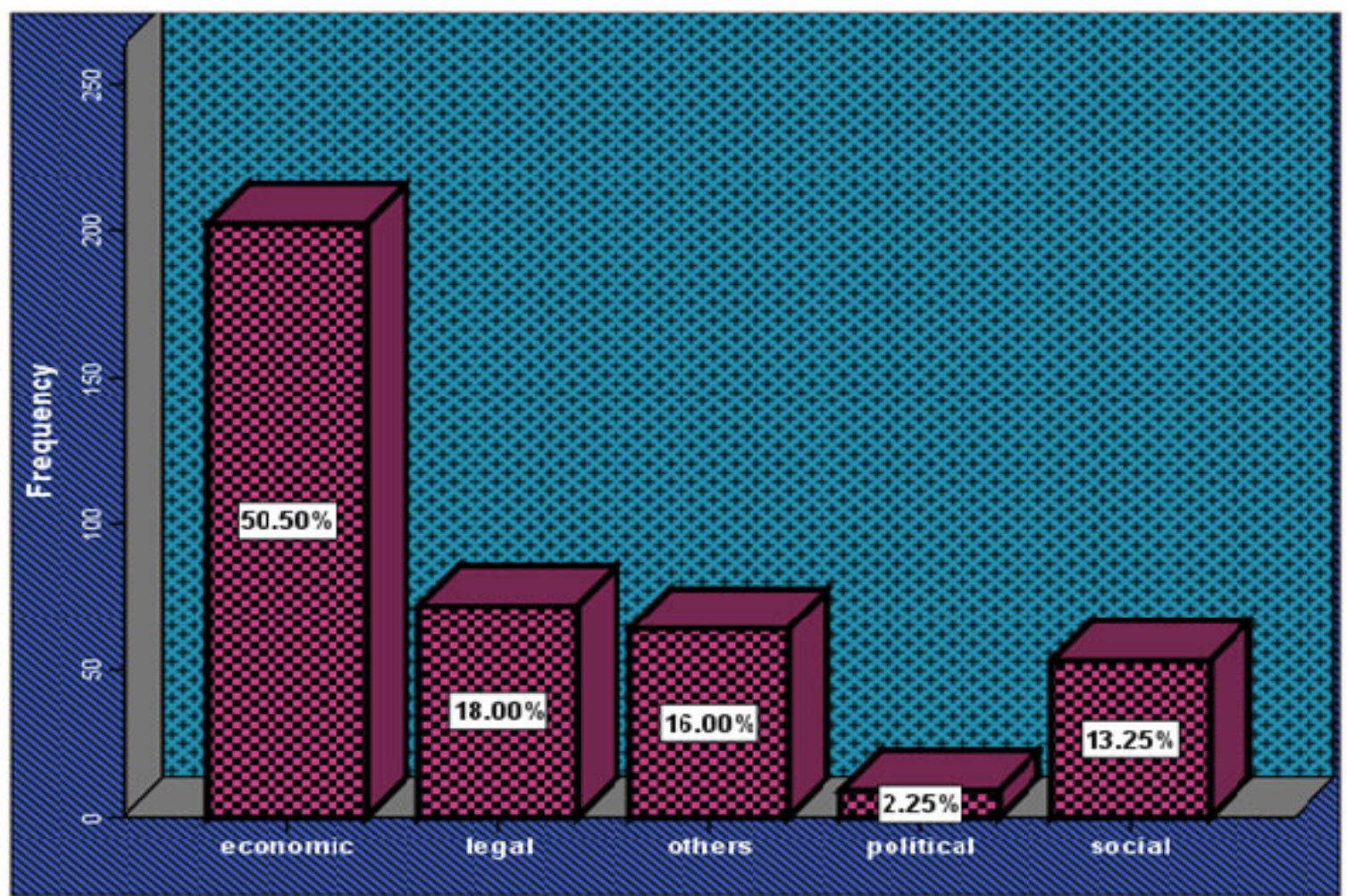

Figure 11. Opportunities needed to increase social status

Still now women garment worker does not have standard social status in our society. They need some opportunities to increase their social status which is related to social, economic, political, legal etc. Increasing their salary, ensuring social compliance and legal protection is more important to confirm their social status. In the context of the role of stakeholder to increase social status, these opportunities are needed to increase the social status.

They need a permanent job which ensures the economic support. So, if the garments industry or BGMEA can arrange all women garments worker a permanent job then their social status will increase moderately. Increase of social status depends on some opportunities such as economic, legal, political, and social and others. About half of the workers $50.5 \%$ think that they need economic support to increase social status. On the contrary, $18 \%$ needs legal, $13.25 \%$ social and $2.25 \%$ of workers needs political opportunities. $16 \%$ of workers urge for other opportunities such as infrastructure, social safety net services etc.

\section{Policy Suggestion and Recommendations}

In the above discussion about this study, we found a lot of problems hamper the women garments worker. They responded physical harassment, psychological assault, socio-economic discrimination and disempowerment are the prime problem to discourage working in garments sector. So, we can find out some policy suggestion and recommendations to encourage women garments worker, too aware the owner of garments industry, to establish strong relationship between garments worker and owner of the garments industry etc.

(1) Being a stakeholder for promoting social status of women garments workers to save a portion of their salary in their own bank account. Also, garments can motivate women garments worker to determine a targetbased bonus system as well as other incentives such as leaves, health benefit and so on.

(2) To ensure proper working environment and to support women in case of harassment all garments factory need to appoint an Industrial Labour Relation Officer who is helping women garments worker in any problem as well as will coordinate between worker and owner of the garments industry. It is a crying need for appointing an Industrial Labour Relation Officer per 500 or more workers in every garment.

(3) Bangladesh Government as a stakeholder should create pressure to garments industry to ensure the social compliance for the women garments worker by which they would be more benefitted from the garments sector. Social compliance issues are more important for garments industry because it attract the foreign buyers to buy product. Social compliance means working conditions, employment conditions, welfare facilities, forced labor, discrimination, industrial relations etc. that should be ensured for women garments worker.

(4) Competency level of the female garments workers is very low work at lower position and productivity is also poor and hence they get poor salaries and they cannot claim for more. If the competency level of the workers can be developed then their productivity will increase and they will be able to perform better and will 
earn more. For this development, the owners should establish training centers to make them skilled in different rules and regulations and to make them aware of their responsibilities. Every garment industry should establish separate place for working mothers where they can breast feed their children and can safely keep them there.

(5) For enriching status of women garments workers in the society arranging awareness program to increase positive attitude about women garments worker is essential.

(6) A woman garments worker face different types of violence at home, workplace, and also in public spaces. For reducing harassment/discrimination stakeholders should create awareness among the people about the social norms and legal procedures and every garment should strictly follow the Violence Against Women and Children 2013-2025 so that persecuted women garment worker should also raise their voices to get proper justice.

(7) To make a legal framework for women garments worker which is helpful to ensure social justice into garments industry as well as to maintain a standard social status. Legal framework protects her from any harassment, discrimination in garments industry and family. To prevent sound pollution in the working place and need to ensure proper medical facilities increasing maternity leave as well. Maternity leave should be increased six months for ensuring proper health both for mother and infant.

\section{Conclusion}

Garments industry is a revolutionary development sector in our country. Most of the portion of national income contributes from readymade garments industry and it is highest exporting sector in Bangladesh. Most of the garment's workers are women because they are more available in the industrial area. They are come from poor family and rural areas. Before joining the garments industry, they are deprived from education, health, social function, decision making in family, legal support etc. Garment industries create a supporting opportunity for poor women to their economic solvency. Women garments worker faces various type of harassment/discrimination in garments industry, home and public places. They harassed/discriminated in economic, physical, mental, etc. by their colleagues, supervisor, staffs, owners, relatives, family members, friends etc. In the persecuted moment women garments worker are getting support from their family, colleagues, friends, relatives, and others. Although, they are facing many problems in the garments but they are getting a lot of benefits from the garments industry.

Garment's job gives economic support, which is helping to change their social status. In before joining the garments industry they have no controlling power over resources. They are also depending on their family members economically. They have no decision-making power in their family issues. Now they contribute in family income which will make economic solvency. After joining the garments industry, they are taking decision in their family issues and they also take control over resources. Quality of health service improves after joining the garments industry but services were not good in before joining the garments. Stakeholders like garments industry, governments, media helps to ensure benefits for women garments worker which are helpful for changing their social status. They also insist on the garments industry to ensure social compliance, it will more favourable to increase social status of women garments worker.

\section{References}

A Handbook on the Bangladesh Labor Act, 2006.

Abdin, M.J (2008). "Women Empowerment in Bangladesh". Social Science Research Network. PP. 1-17

Absar, S. S. (2001). "Problems Surrounding Wages: The Readymade Garment Sector in Bangladesh." Labor Management in Development Journal, Vol. 2, No. 7, PP. 3-17

Absar, S. S. (2002). "Women Garment Workers in Bangladesh.” Economic and Political Weekly, Vol.37, No.29, $3012-3016$.

Ahamed, F. (2013). "Improving Social Compliance in Bangladesh's Ready-Made Garment Industry.” Labor and Management in Development, PP. 1-26.

Ahmed, F. E. (2004). "The Rise of the Bangladesh Garment Industry: Globalization, Women Workers, and Voice.” NWSA Journal, Vol. 16, No.2, PP. 34-45.

Ahmed, J. U. and Hossain, T. (2009). "Industrial Safety in the Readymade Garment Sector: A Developing Country Perspective”. Sri Lankan Journal of Management, Vol. 14, No.1, PP. 1-13.

Alam, Jafar. (2006). 'Security and Environment condition in Garment', Page.5

Alam, M., and Rabbani, M. G. (2007). "Vulnerabilities and Responses to Climate Change for Dhaka." Environment and Urbanization, Vol. 19, No.1, PP. 81-97.

Amin, S., Diamond, I., Naved, R. T., and Newby, M., (1998). "Transition to Adulthood of Female GarmentFactory Workers in Bangladesh". Studies in Family Planning, Vol. 29. No.2, PP. 185-200.

Bangladesh Institute of Development Studies (BIDS), Dhaka, Bangladesh.

Bangladesh Garment Manufacturers and Exporters Association (BGMEA), Dhaka, Bangladesh.

Bangladesh labour force survey (1999-2000). BBS, Planning Division, Ministry of planning. Government of the 
people's republic of Bangladesh.

Begum, Najmen Nur. (1997). Women in Ready Made Garment Industries: Issues and concerns. The journal of social development, Institute of social welfare and research, Dhaka University, Dhaka. Vol.12, No-1, December.

Boas, M., Kathleen, J. and Shaw, T. (2006). "Dealing with Conflicts and Emergency Situations in Vandana, D. and Rob, R. (eds.), Doing Development Research. London: Sage Publications Ltd., PP.70-79.

Breen, L. J. (2007). "The Researcher in the Middle: Negotiating the Insider/Outsider Dichotomy." The Australian Community Psychologist, Special Edition Papers, Vol. 19, No.1, PP.163-174.

Browne, K. (2005). "Snowball Sampling: Using Social Networks to Research Non- Heterosexual Women". International Journal of Social Research Methodology, Vol. 8, No. 1, PP.47-60.

Bryman. A. (2012). Social Research Methods (4th ed.). Oxford University Press: New York.

Cain, M., Khanam, S. R., and Nahar, S. (1979). "Class Patriarchy and Women's Work in Bangladesh." Population and Development Review, Vol.5, No.3, PP. 405-438.

Caldwell, K., and Atwal, A. (2005). "Non-Participant Observation: Using Video Tapes to Collect Data in Nursing Research.” Nurse Researcher, Vol.13, No. 2, PP. 42-54.

Chavez, C. (2008). "Conceptualizing from the Inside: Advantages, Complications, and Demands on Insider Positionality." The Qualitative Report, Vol. 13, No.3, PP. 474-494.

Cohen, N., and Arieli, T. (2011). "Field Research in Conflict Environments: Methodological Challenges and Snowball Sampling." Journal of Peace Research, Vol.48, No.4, PP.423-435.

Cornwall, A., and Anyidoho, N. A. (2010). "Introduction: Women's Empowerment: Contentions and Contestations." Development Journal, Vol. 53, No.2, PP., 144-149.

DiCicco-Bloom, B., and Crabtree, B. F. (2006). "The Qualitative Research Interview". Medical Education, Vol.40, No. 4, PP.314-321.

Dwyer, S. C., and Buckle, J. L. (2009). "The Space Between: On Being an Insider-Outsider in Qualitative Research". International Journal of Qualitative Methods, Vol. 8, No.1, PP 54-63.

Feldman, S. (2001). "Exploring Theories of Patriarchy: A Perspective from Contemporary Bangladesh." Signs, Vol.26, No.4, PP. 1097-1127.

Fitzpatrick, R., and Boulton, M. (1994). “Qualitative methods for assessing health care”. Quality in health care, Vol.3, PP.107-113

Fournillier, J.B. (2012). Agency and Empowerment. Georgia State University.

Galtung, J. (1980). "The Changing Interface between Peace and Development in a Changing World." Security Dialogue, Vol.11, No. 2, PP. 145-149.

Galtung, J. (1990). "Cultural Violence.” Journal of Peace Research, Vol.27, No.3, PP.291-305.

Gray, C., and Malins, J. (2004). Visualizing Research: A Guide to Research Process in Art and Design. Alder shot, Ash gate Publishing Ltd.

Harding, S. G. (1986). The Science Question in Feminism. Cornell University Press: London.

Hellawell, D. (2006). "Inside-Out: Analysis of the Insider-Outsider Concept as a Heuristic Device to Develop Reflexivity in Students Doing Qualitative Research.” Teaching in Higher Education, Vol.11, No.4, PP. 483494.

Ho, K. H. (2007). “Structural Violence as a Human Rights Violation.” Essex Human Rights Review, Vol.4, No. 2, 1-17.

Hossain, S. (2008). "Rapid Urban Growth and Poverty in Dhaka City.” Bangladesh e-Journal of Sociology, Vol.5, No.1, PP. 1-24

Hossain, N. (2012). "Women's Empowerment Revisited: From Individual to Collective Power among the Export Sector Workers of Bangladesh.” IDS Working Papers, Vol. 2012, No.389, PP. 1-40.

Hossain, I. and Al-Amin, M. (2012). "Employment of Women in the Globalization of Production in the ReadyMade Garment sector of Bangladesh: Welfare or Exploitation?" Empowerment, Vol. 19, Women for Women, Dhaka, Bangladesh PP. 1-16

Huda, S. (2006). "Dowry in Bangladesh: Compromising Women's Rights. South Asia Research.” Vol. 26, No. 3, PP. 249- 268.

Islam, M. T. (2010). "Violence against Women in Bangladesh: A Structural Setback to Peace and Security." Pakistan Journal of Criminology, Vol. 2, No.2, PP. 53-76.

Jamaly, R., and Wickramanayake, E. (1996). "Women Workers in the Garment Industry in Dhaka, Bangladesh." Development in Practice, Vol. 6, No. 2, PP. 156-161.

Kabeer, N. (1997). "Women, Wages and Intra-Household Power Relations in Urban Bangladesh." Development and Change, Vol.28, No.2, PP. 261-302.

Kabeer, N. (1999). "Resources, Agency, Achievements: Reflections on the Measurement of Women's Empowerment." Development and Change, Vol.30, No.3, PP. 435-464.

Kabeer, N. (2001). "Resources, Agency, Achievements: Reflections on the Measurement of Women's 
Empowerment" in Sisak, A. (ed.), Discussing Women's Empowerment. Theory and Practice. Sida Studies no. 3, PP.17-57.

Kabeer, N. (2005). "Gender Equality and Women's Empowerment: A Critical Analysis of the Third Millennium Development Goal 1.” Gender and Development, Vol. 13, No.1, PP.13-24.

Khatun, F., Rahman, M., Bhattacharya, D., and Moazzem, K.G. (2008). Gender and Trade Liberalization in Bangladesh: The Case of the Readymade Garments. CPD Research Monograph 2, Centre for Policy Dialogue, Dhaka, Bangladesh.

Khosla, N. (2009). "The Ready-made Garment Industry in Bangladesh: A Means to Reducing Gender-Based Social Exclusion of Women?” Journal of International Women's Studies, Vol.11, No.1, PP. 289-303.

Kibria, N. (1995). "Culture, Social Class, and Income Control in the Lives of Women Garment Workers in Bangladesh." Gender and Society, Vol.9, No.3, PP. 289-309.

Kibria, N. (1998). Becoming a Garments Worker: The Mobilization of Women into the Garments Factories of Bangladesh. Geneva: United Nations Research Institute for Social Development. Occasional paper 9, PP. 122

Klasen, S. (2000). Does Gender Inequality Reduce Growth and Development? Evidence from Cross-Country Regressions. Ludwig-Maximilians-Universität München.

Lorber, J. (2010). Gender Inequality: Feminist Theories and Politics. (4th ed.) Oxford University Press: Oxford.

Mahmud, S. (2003). "Is Bangladesh Experiencing a Feminization of Labor Force?" The Bangladesh Development Studies, Vol. 29, No. 1/2, PP. 1-37.

Marshall, M. N. (1996). "Sampling for Qualitative Research.” Family practice, Vol. 13, No.6, PP. 522-525.

Mosedale, S. (2005). "Assessing women's empowerment: towards a conceptual framework". Journal of International Development. Vol. 17, No. 2, PP. 243-257.

Mottaleb, K.A and Sonobe, T. (2011). "An inquiry into the rapid growth of the garment industry in Bangladesh." Economic Development and Cultural Change, Vol. 60, No. 1, PP. 67-89.

Muni, N. (2006). "Women Empowerment: Dynamics and Dimensions" in Dasarathi B., and R.L. Panigrahy (eds.), Women Empowerment, Discovery Publishing House: New Dehli, PP. 24-30.

Naples, N. A. (1996). "A Feminist Revisiting of the Insider/Outsider Debate: The Outsider Phenomenon in Rural Iowa.” Qualitative Sociology, Vol. 19, No.1, PP. 83-106.

Paul-Majumder, P. and Chowdhury, Jahir. (1994). 'Socio-economic condition of Garment working women in Bangladesh.' Dhaka Acota publication limited.

Paul-Majumder, P. (2000). "Violence and Hazards Suffered by Women in Wage Employment." Empowerment, Vol. 7, Women for Women, Dhaka, Bangladesh. PP. 1-30

Paul-Majumder, P., and Begum, A. (2000). The gender imbalances in the export-oriented garment industry in Bangladesh. Policy Research Report on Gender and Development, Working paper series no. 12. The World Bank, Development Research Group/Poverty Reduction and Economic Management Network, PP. 1-40.

Rabe, M. (2003). "Revisiting Insiders and Outsiders as Social Researchers". African Sociological Review, Vol.7, No.2, PP. 149-161.

Rashid, M. A. (2006). Rise of Readymade Garments Industry in Bangladesh: Entrepreneurial Ingenuity or Public Policy. Paper Presented at the Workshop on Governance and Development Organized by the World Bank and BIDS at Dhaka on 11-12 November, 2006.

Reza, Kazi Rina. (2005). 'Miserable condition of Garment worker: RMG Sector of Bangladesh and its worker., Second National convention, Bangladesh Garment Labor Federation, Dhaka.page-5.

Rhee, Y.W. (1990). "The Catalyst Model of Development: Lessons from Bangladesh's Success with Garment Exports." World Development, Vol. 18, No. 2, PP. 333-346.

Sen, A. (2001). "The Many Faces of Gender Inequality.” New republic, PP. 466-477.

Silverman, D. (2005). Doing Qualitative Research: A Practical Handbook (2nd ed.). Sage Publications: London.

Stanistreet, D., Bambra, C., and Scott-Samuel, A. (2005). "Is Patriarchy the Source of Men's Higher Mortality?" Journal of Epidemiology and Community Health, Vol.59, PP. 873-876.

The Daily Star, July 4, 2013. Pre -hartal terror.

Tongco, M.D.C. (2007). "Purposive Sampling as a Tool for Informant Selection." Ethnobotany Research and Applications, Vol.5, PP. 147-158.

Wood, E. J. (2006). "The Ethical Challenges of Field Research in Conflict Zones." Qualitative sociology, Vol. 29, PP. 373-386.

World Bank, (2002). Empowerment and Poverty Reduction: A Source Book.

World Health Organization (WHO), (2001). Putting Women First: Ethical and Safety Recommendations for Research on Domestic Violence against Women, Geneva.

Wright. D (2000). "Industrialization and the Changing Role of Women in Bangladesh." Asian Studies Review, Vol. 24, No. 2, PP.231-242.

Yardley, J. (2013). Report on Deadly Factory Collapse in Bangladesh Finds Widespread Blame. The New York 
Times.

Yunus, M., and Yamagata, T. (2012). "The Garment Industry in Bangladesh", in Fukunishi(ed.), Dynamics of the Garment Industry in Low-Income Countries: Experience of Asia and Africa (Interim Report). Chousakenyu Houkokusho, IDE-JETRO, PP. 1-26 